\author{
B.Kh. Mussabayeva, Zh.S. Kassymova, M.A. Aldabergenova \\ Shakarim State University of Semey, Kazakhstan \\ (E-mail: binur.mussabayeva@mail.ru)
}

\title{
Interpolymer complex of biopolymers as a soil structure-forming agent
}

\begin{abstract}
An interpolymer complex based on biopolymers — chitosan (CS) and sodium alginate (AlNa) was synthesized. The chitosan-sodium alginate interpolymer complex was prepared by mixing equimolar solutions of polymers in a given proportion. Chitosan solution in citric acid and aqueous solution of sodium alginate were used. The composition of the interpolymer complex is determined by the methods of gravimetry, turbidimetry and dynamic laser light scattering and is $[\mathrm{CS}]:[\mathrm{AlNa}]=2: 3$. Interpolymer complex is formed as a result of ion-ion interaction between cationic polyelectrolyte chitosan and anionic polyelectrolyte sodium alginate. Agrochemical parameters of soil were determined without and with treatment of certain biopolymers and interpolymer complex. Soil treatment by the individual biopolymers and the prepared interpolymer complex has not been appreciably affected in its basic agrochemical parameters. As a result of laboratory experiments, it is shown that the prepared interpolymer complex is more effective means of protecting the soil from water erosion in comparison with individual biopolymers. Vegetation experiments in the laboratory revealed that soil treatment interpolymer complex has a positive effect on the growth and development of cucumber. Consequently, the synthesized interpolymer complex can be used as an effective environmentally sound structure-forming agent for the soil.
\end{abstract}

Keywords: interpolymer complex, biopolymers, chitosan, sodium alginate, composition, soil, structure-forming agent.

\section{Introduction}

Desertification and degradation of agricultural soils is one of the global problems of our time [1]. Currently, the main reasons for the deterioration of soil quality are water and wind erosion, irrational use of land. As a result, part of the fertile land is useless for arable land every year. This leads to genetic changes in the soil and leads to the process of degradation. The structure and water-physical properties of the soil are changing under the influence of anthropogenic factors, which leads to a decrease in its fertility.

Restoration of fertility and erosion control are clearly impossible without improvement of soil waterphysical properties. Therefore, optimization of water-physical properties and stabilization of soil structure is one of the most important tasks in the field of soil ecology. One of the optimal ways to improve the structural and aggregate state of soils is the treatment of the top layer of soil by interpolymer complexes (IPCs) [2].

Surface treatment of soil IPC allows to achieve soil consolidation for 3-5 years, can prevent water and wind erosion and the associated spread of various contaminants [3], marked air and water permeability of coatings IPC [2, 4-6]. Ecologically safe biopolymers and IPC based on them are promising structure-forming agents [7-8].

The goal of research is the preparation of IPC based on the biopolymers - chitosan (CS) and sodium alginate (AL), to study the structure-forming properties of IPC and the effect on the growth and development of vegetable crops.

\section{Experimental}

High molecular weight chitosan with a molecular weight of $190 \mathrm{kDa}$, degree of deacetylation $85 \%$, Sigma-Aldrich (Germany). $10^{-2} \mathrm{M}$ solution of chitosan in $3 \%$ citric acid were used. Sodium alginate with a molecular weight of $440 \mathrm{kDa}$ manufactured by Sigma-Aldrich (China), used $10^{-2} \mathrm{M}$ aqueous alginate solution [9-10]. The composition of IPC was determined by the following methods: gravimetry, turbidimetry and dynamic laser light scattering.

For study the formation of IPC by gravimetric method, a series of solutions with different volume ratios of equimolar solutions $\left(10^{-2} \mathrm{~mol} / \mathrm{l}\right)$ of $\mathrm{CS}$ and AL were prepared according to Table 1 . 
Ratio of components to preparation IPC

\begin{tabular}{|c|c|c|}
\hline \multirow{2}{*}{ Ratio } & \multicolumn{2}{|c|}{ The volume of solution, $\mathrm{ml}$} \\
\cline { 2 - 3 } & $\mathrm{CS}$ & $\mathrm{AL}$ \\
\hline$[100]:[0]$ & 10 & 0 \\
\hline$[90]:[10]$ & 9 & 1 \\
\hline$[80]:[20]$ & 8 & 2 \\
\hline$[70]:[30]$ & 7 & 3 \\
\hline$[60]:[40]$ & 6 & 4 \\
\hline$[50]:[50]$ & 5 & 5 \\
\hline$[40]:[60]$ & 4 & 6 \\
\hline$[30]:[70]$ & 3 & 7 \\
\hline$[20]:[80]$ & 2 & 8 \\
\hline$[10]:[90]$ & 1 & 9 \\
\hline$[0]:[100]$ & 0 & 10 \\
\hline
\end{tabular}

The resulting solutions were mixed in a rotator for 6 hours, then centrifuged for 15 minutes at a rotation speed of $3500 \mathrm{rpm}$, then drained the liquid and weighed the wet precipitation.

For study the formation of IPC by turbidimetric method, after mixing the obtained solutions in accordance with Table 1, the optical density of each solution was measured on the spectrophotometer Specord 210 plus (Analytik Jena, Germany) at a wavelength of $400 \mathrm{~nm}$. Based on the received data, a graph of the dependence on the composition of the optical density solution was drawn.

The measurements of $\zeta$-potential (macromolecule recharge) carried out by dynamic laser light scattering method on the device Zetasizer Nano ZS90 (Malvern, UK).

Samples of dark chestnut soil of the dry steppe zone of the East Kazakhstan region were selected in $5 \mathrm{~km}$ from the Vodnyi village near Semey town. The study of the main agrochemical parameters of the soil, such as: field humidity, acidity, moisture capacity, water resistance, nutrient content (phosphorus, nitrogen), organic matter and humus content was carried out according to the generally accepted methods.

To study the soil resistance to water erosion, glass Petri dishes were used in the model experiment. In each dish is introduced $50 \mathrm{~g}$ of the sample in dark-chestnut soil, sifted through a sieve $d=0.25 \mathrm{~mm}$. the Soil in the first Cup of dry (control, polymers and IPC not included), the soil in 2-dish handled IPC [CS]:[AL] = $=2: 3$, the soil in the 3-dish was administered $12.5 \mathrm{ml}$ of $10^{-3} \mathrm{M}$ of chitosan dissolved in $3 \%$ citric acid, 4-dish was administered $12.5 \mathrm{ml}$ of $10^{-3} \mathrm{M}$ aqueous solution of sodium alginate. All cups were dried for 5 days at $t=20^{\circ} \mathrm{C}$. The dried soil samples were then tilted $15^{\circ}$ and $100 \mathrm{ml}$ of distilled water was sprayed. Washing water was collected in glass flasks.

Vegetation experiments were carried out in the laboratory at a temperature of $20^{\circ} \mathrm{C}$. Wagner vessels measuring $1.7 \mathrm{dm}^{3}$ and a surface area of $1.68 \cdot 10^{-2} \mathrm{~m}^{2}$ were used as soil containers. Before the experiment, the vessels were cleaned of mechanical impurities, the dishes were rinsed with running water, and then with distilled water. The average soil sample was taken. To ensure the moisture content of the lower soil layer at a depth of $2 \mathrm{~cm}$ from the bottom with the compaction of the first layer, glass tubes were placed. The vessels were filled with soil $10 \mathrm{~cm}$ high from the bottom of the vessel, leaving $2.5 \mathrm{~cm}$ from the upper edge of the vessel. Each vessel is signed in accordance with the experience option.

For vegetation experiments as a vegetable culture cucumber (Cucumis) «Kustovoy» was selected, which is cultivated in many regions of the Kazakhstan.

Harvesting of plant seeds. Seeds of cucumbers of the «Kustovoy» variety were placed in glass Petri dishes and germinated between the filter paper moistened with pre-distilled water in the dark. From the seeds laid for the vegetation experiment, intact seeds with well-developed roots were selected. Planting of plant seeds. Soil treatment with biopolymers and IPC by two-solution method was carried out according to the following scheme:

1. Control experience - not included biopolymers and IPC.

2. Treatment by CS $\left(8.05 \cdot 10^{-3} \mathrm{~g} / \mathrm{vessel}\right)$.

3. Treatment by AL $\left(5 \cdot 10^{-2} \mathrm{~g} / \mathrm{vessel}\right)$.

4. Treatment by IPC [CS]:[AL] $=2: 3\left(6.44 \cdot 10^{-3} \mathrm{~g} /\right.$ vessel $\left.: 6 \cdot 10^{-2} \mathrm{~g} / \mathrm{vessel}\right)$. 
5. Introduction of dry mixed fertilizer «Vyrastaika» $\left(\mathrm{NH}_{4}\right)_{2} \mathrm{SO}_{4}-\left\{\mathrm{NH}_{4} \mathrm{H}_{2} \mathrm{PO}_{4}+\left(\mathrm{NH}_{4}\right)_{2} \mathrm{HPO}_{4}\right\}-$ $-\mathrm{KH}_{2} \mathrm{PO}_{4}=12-14-16$ (0.84 g/vessel).

6. Treatment by IPC and dry mixed fertilizers.

After tillage, cucumber seeds were planted, the distance between them was kept from $2 \mathrm{~cm}$ to 4 rows in each. Planting depth $1 \mathrm{~cm}$. Top layer of soil is moistened with purified water from a spray bottle, resulting in a restoration of a polymer film in the surface of soil. Watering of the soil was carried out once in 2 days, keeping 60 percent of the full moisture capacity. Every day the vessels were moved in randomized mode to avoid the impact of external factors on the development of the plant. The emergence of the first shoots and the appearance of mass shoots were observed, daily evaluation of biometric parameters of the organs of terrestrial growth was conducted as well.

\section{Results and Discussion}

The results of gravimetric and turbidimetric studies of complexation and measurements of $\zeta$-potential (macromolecule recharge) showed that the composition of IPC is formed [CS]:[AL] $=4: 6$ or 2:3 (Figs. 1-3).

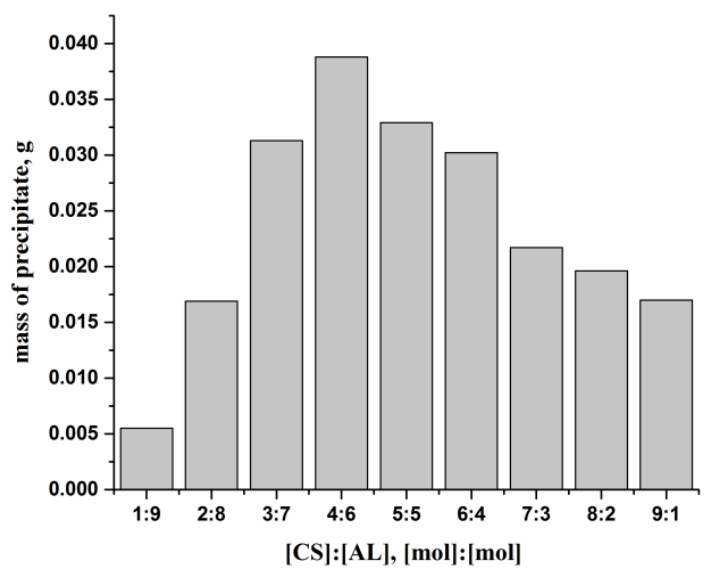

Figure 1. Chart based on weight of solids, the ratio [CS]:[AL]

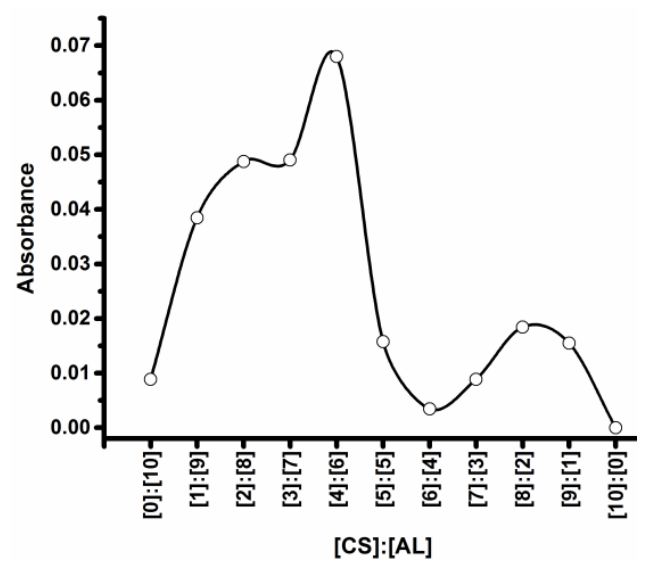

Figure 2. The dependence of the light absorption ratio [CS]:[AL]

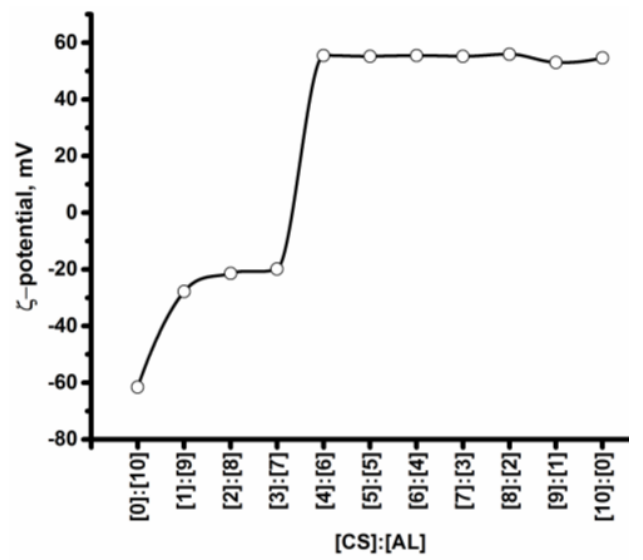

Figure 3. The dependence of the $\zeta$-potential on the composition IPC

Previously, we have prepared a IPC structure [CS]:[AL] = 1:4 [11]. However, in that work chitosan was dissolved in hydrochloric acid, in this work chitosan is dissolved in citric acid. Thus, the nature of the solvent affects the composition of the prepared IPC. Agrochemical parameters of soil without treatment and after treatment of separate biopolymers and IPC are determined. Table 2 shows that biopolymers and IPC do not change the $\mathrm{pH}$ of the aqueous extract and increase the $\mathrm{pH}$ of the salt extract. There was no noticeable effect on other soil parameters. 


\section{Agrochemical parameters of soil}

\begin{tabular}{|c|c|c|c|c|}
\hline \multirow{2}{*}{ Structurant } & \multicolumn{4}{|c|}{ Agrochemical parameters } \\
\cline { 2 - 5 } & $\mathrm{pH}_{\text {water }}$ & $\mathrm{pH}_{\text {salt }}$ & $\mathrm{NH}_{4}^{+}, \mathrm{mg} / \mathrm{g}$ soil & $\mathrm{P}_{2} \mathrm{O}_{5}, \mathrm{mg} / \mathrm{g}$ soil \\
\hline Before making & 6.909 & 7.207 & 0.61 & 2.25 \\
\hline $\mathrm{CS}$ & 6.917 & 7.560 & 0.62 & 2.25 \\
\hline $\mathrm{AL}$ & 6.921 & 7.581 & 0.61 & 2.23 \\
\hline IPC & 6.926 & 7.552 & 0.67 & 2.27 \\
\hline
\end{tabular}

Figure 4 shows the results of a study of soil resistance to water erosion. There is soil erosion in the control experiment and in the dish treated with individual polymers. The washout is not observed only in the dish treated with IPC.
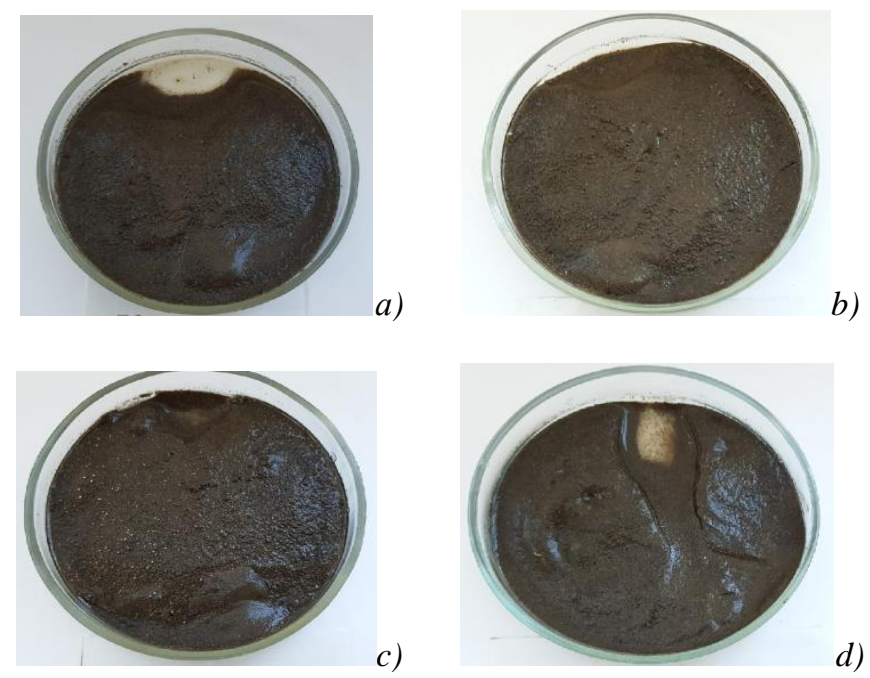

$a$ - control; $b-$ soil treated with IPC; $c$ - soil treated with chitosan; $d$ - soil treated with sodium alginate

Figure 4. Soil after spraying with distilled water

Each experiment was repeated three times. The washing water of the soil treated by IPC is the most transparent in comparison with other washing waters. Then the soil samples were dried for another 5 days at $t=20^{\circ} \mathrm{C}$ and weighed. According to the results of calculations, a diagram of soil resistance to water erosion was designed (Fig. 5).

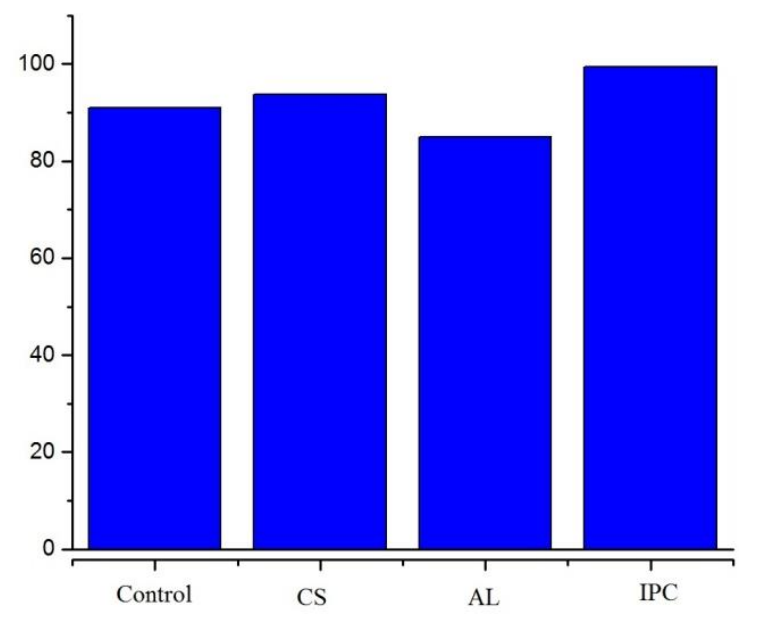

Figure 5. Diagram of soil resistance to water erosion, \% 
Thus, it was shown that the IPC of $[\mathrm{CS}]:[\mathrm{AL}]=2: 3$, is the most effective means to protect the soil from water erosion.

The results of vegetation experiments for 32 days are shown in Figures 6-8.

The period from sowing before the appearance of initial seedlings was 8 daysand before mass seedlings - 12 days. In this case, the initial and mass germination in the experiment with IPC and IPC + fertilizer was $8-10 \%$ higher than the control. Cucumber varieties «Kustovoy» refers to bee pollinated and 30-40 days after the emergence of seedlings, it is advisable to transplant the seedlings into open ground.

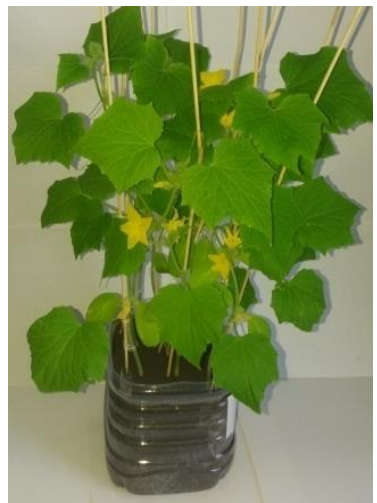

Control

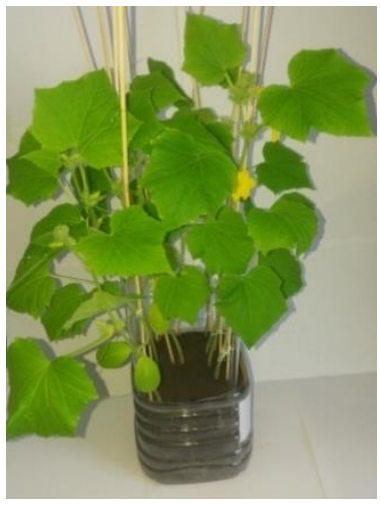

IPC

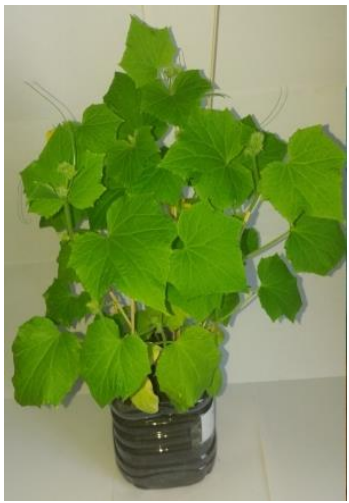

CS

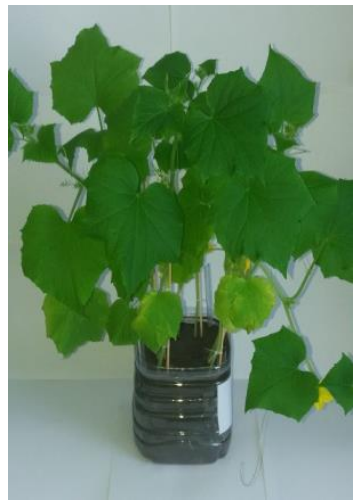

Fertilizer

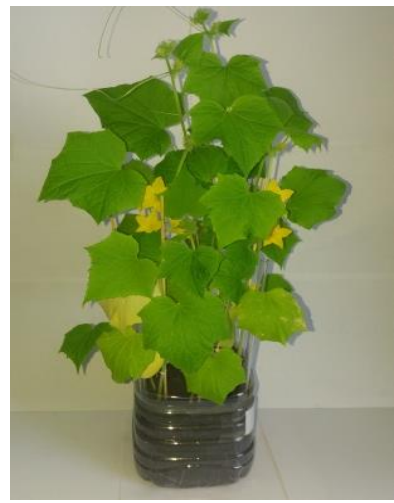

AL

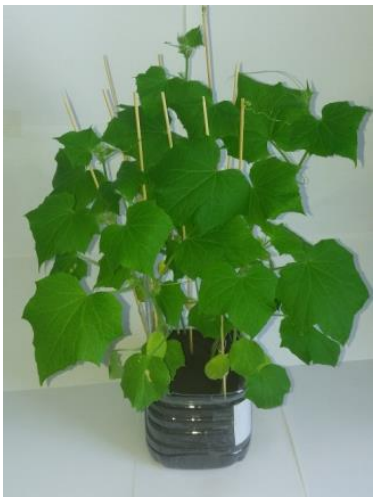

IPC with fertilizer

Figure 6. Growing experience in the vessels of Wagner

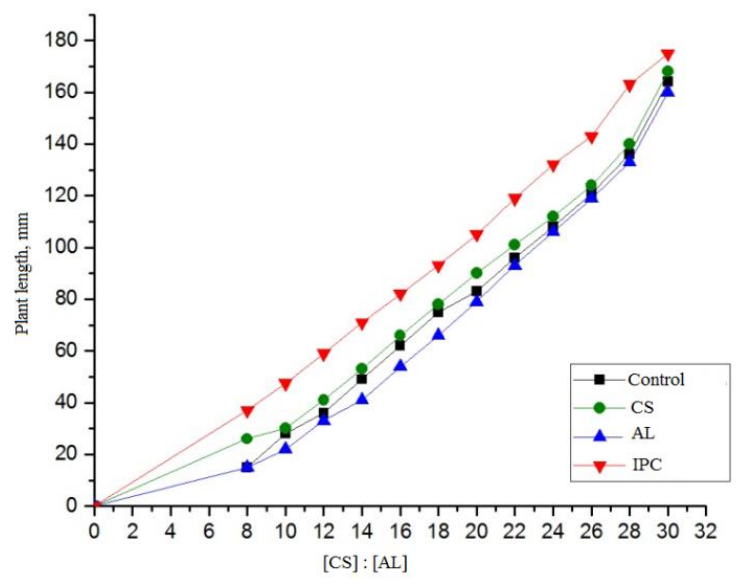

Figure 7. Dynamics of growth of cucumber during the technology of processing of soil biopolymers and IPC based on them

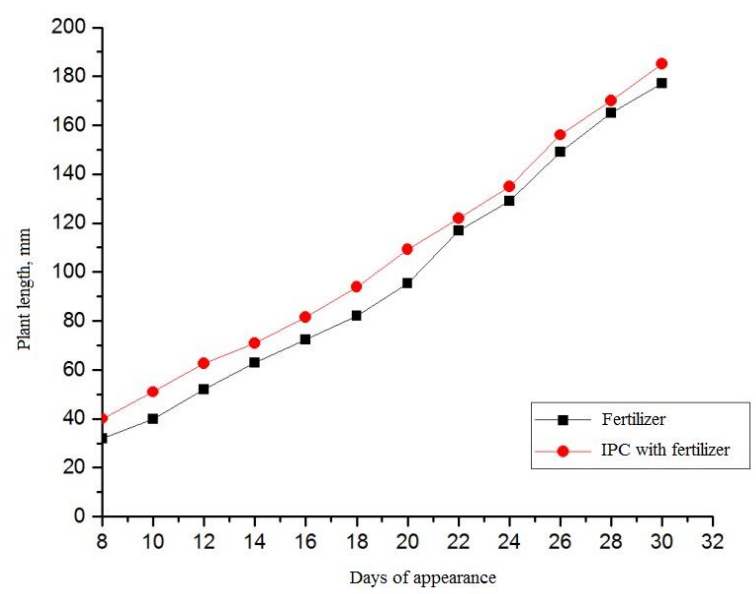

Figure 8. Dynamics of cucumber growth in soil treatment technology IPC with fertilizer 
According to the results of biometric observation at the end of the growing season, the height of the main stem of the cucumber in the experimental variants was $47.2 \mathrm{~cm}$ (with CS), $40.5 \mathrm{~cm}$ (with AL), $49.7 \mathrm{~cm}$ (with IPC), $61.2 \mathrm{~cm}$ (with fertilizer), $71 \mathrm{~cm}$ (with IPC and fertilizer), and $39.5 \mathrm{~cm}$ in the control variant (Fig. 7, 8). The greatest development of the root system was registered for the experimental variants with IPC (biomass was $0.41 \mathrm{~g}$, length of the main root $7.3 \mathrm{~cm})$ and with IPC + fertilizer $(0.40-0.45 \mathrm{~g}$ and $8.8-10.0 \mathrm{~cm})$. We also recorded the stimulating effect of IPC and fertilizer on the development of parameters such as leaf length $(9.7-10.5 \mathrm{~cm})$, while there was no difference between the options in the number of leaves (7-8 pcs) and flowers (1-2 pcs)) for one plant.

Therefore, it was found that IPC has a positive effect on the growth and development of cucumber.

\section{Conclusion}

IPC on the basis of biopolymers of chitosan and sodium alginate was prepared. The composition of the IPC determined by the gravimetric, turbidimetric and dynamic laser light scattering methods and is [CS]:[AL] $=2: 3$. Soil treatment by the individual biopolymers and the resulting IPC is not appreciably affected in its main agrochemical properties, however, processing IPC has greatly improved the resistance of soil to water erosion. Vegetation experiments in the laboratory revealed that soil treatment IPC has a positive effect on the growth and development of cucumber. Thus, it can be concluded that the IPC of the composition [CS]:[AL] = 2:3 can be used as an effective, environmentally compatible soil structure-forming agent.

The study was carried out with the financial support of the Ministry of education and science of the Republic of Kazakhstan, grant AP 05134681.

\section{References}

1 Lü Y.H. Land degradation research: the need for a broader focus / Y.H. Lü, B.J. Fu, L. Lin // Environmental Science \& Technology. - 2015. - Vol. 49. - P. 689-690.

2 Kabanov V.A. Polyelectrolytes in the solution of ecological problems / V.A. Kabanov, A.B. Zezin, V.A. Kasaikin, A.A. Yaroslavov, D.A. Topchiev // Russian Chemical Reviews. - 1991. - Vol. 60, No. 3. - P. 288-291.

3 Chelushkin P.S. Interpolyelectrolyte complexes of a cationic amphiphilic diblock copolymer and an oppositely charged linear polyanion / P.S. Chelushkin, E.A. Lysenko, T.K. Bronich, A. Eisenberg, A.V. Kabanov, V.A. Kabanov // Polymer Science. A. 2004. - Vol. 46, No. 5. - P. 485-492.

4 Zezin A.B. Polymeric stabilizers for protection of soil and ground against wind and water erosion / A.B. Zezin, S.V. Mikheikin, V.B. Rogacheva, M.F. Zansokhova, A.V. Sybachin, A.A. Yaroslavov // Advances in Colloid and Interface Science. — 2015. — Vol. 226. - P. 17-23.

5 Inagamov S.Ya. Structure and Physical-Mechanical Properties of Interpolymeric Complexes Based on Sodium Carboxymethylcellulose / S.Ya. Inagamov, G.I. Mukhamedov // Journal of Applied Polymer Science. — 2011. — Vol. 122, No. 3. — P. 1749-1757.

6 Orazzhanova L.K. Binary and ternary polymer-strontium complexes and the capture of radioactive strontium-90 from the polluted soil of the Semipalatinsk Nuclear Test Site / L.K. Orazzhanova, M.G. Yashkarova, L.A. Bimendina, S.E. Kudaibergenov // Journal of Applied Polymer Science. - 2003. - Vol. 87, No. 5. - P. 759-764.

7 Мусабаева Б.Х. Применение интерполимерных комплексов в экологических целях / Б.Х. Мусабаева, А.Н. Кливенко, Ж.С. Касымова, Л.К. Оразжанова // Хим. журн. Казахстана. — 2018. — Т. 64, № 4. — С. 187-204.

8 Kassymova Zh.S. Preparation and Properties of Interpolymer Complexes Capable of Soil Structuring / Zh.S. Kassymova, L.K. Orazzhanova, A.N. Klivenko, B.Kh. Mussabayeva, D.K. Asserganov // Russian Journal of Applied Chemistry. — 2019. Vol. 92, No. 2. - P. 208-217.

9 Смирнова Н.Н. Интерполиэлектролитное комплексообразование сульфонатсодержащего ароматического полиамида в водных растворах: влияние природы полиоснований на состав образующихся продуктов / Н.Н. Смирнова // Вестн. ВГУИТ. - 2018. - T. 80, № 1 . - С. 206-210.

10 Панов Д.А. Влияние хитозана на физико-химические свойства альгината натрия / Д.А. Панов // Уч. зап. Крым. федер. ун-та им. В.И. Вернадского. Биология. Химия. - 2018. - № 4(70). - С. 311-319.

11 Kassymova Zh.S. Preparation of interpolymer complexes of chitosan and sodium alginate / Zh.S. Kassymova, L.K. Orazzhanova, B.B. Bayakhmetova, B.S. Gaisina, N.B. Kassenova, G.T. Yelemessova // Bulletin of the Karaganda University. Chemistry Series. - 2019. - No. 1(93). - P. 17-24. 


\title{
Б.Х. Мұсабаева, Ж.С. Қасымова, М.А. Алдабергенова Биополимерлердің интерполимерлі комплексі
топырақ құрылымтүзушісі ретінде
}

Хитозан (ХТ3) және натрий альгинаты (АлNa) биополимерлері әрекеттесуі арқылы интерполимерлі комплекс (ИПК) синтезделді. Хитозан - натрий альгинаты интерполимерлі комплексі полимерлердің эквимолярлық ерітінділерін әр түрлі пропорцияда араластыру әдісімен алынды. ИПК синтездеу үшін хитозанның лимон қышқылындағы ерітіндісі мен натрий альгинатының сулы ерітіндісі пайдаланылған. Түзілген интерполимерлі комплекс құрамы гравиметрия, турбидиметрия және динамикалық лазерлік жарық шашырау әдістерімен анықталған және [XT3]:[АлNa] = 2:3 тең. ИПК катионды полиэлектролит хитозан мен анионды полиэлектролит натрий альгинаты арасындағы ион-иондық әрекеттесу нәтижесінде түзіледі. Топырақ үлгілерінің агрохимиялық көрсеткіштерін жеке биополимерлерді ИПК енгізбестен және енгізгеннен кейін анықтаған. Топырақты жеке биополимерлермен және алынған ИПК-мен өңдеу оның негізгі агрохимиялық көрсеткіштеріне айтарлықтай әсер еткен жоқ. Жеке биополимерлермен, яғни комплекс компоненттерімен және синтезделген ИПК-мен жүргізілген зертханалық тәжірибе нәтижесінде жеке биополимерлермен, яғни комплекс компоненттерімен салыстырғанда алынған интерполимерлі комплекс топырақты су эрозиясынан қорғаудың тиімді құралы болып табылатыны көрсетілген. Зертханалық жағдайда жүргізілген вегетациялық тәжірибе нәтижесінде топырақты ИПК-мен өңдеу көкөністің - қиярдың өсуі мен дамуына оң әсер ететіні анықталды. Демек, биополимерлерден синтезделген ИПК тиімді экологиялық қауіпсіз топырақ құрылымтүзушісі ретінде пайдаланылуы мүмкін деп қорытындылауға болады.

Кілт сөздер: интерполимерлі комплекс, биополимер, хитозан, натрий альгинаты, құрам, топырақ, құрылымтүзуші.

\section{Б.Х. Мусабаева, Ж.С. Касымова, М.А. Алдабергенова \\ Интерполимерный комплекс биополимеров как структурообразователь почвы}

\begin{abstract}
Синтезирован интерполимерный комплекс (ИПК) на основе биополимеров хитозана (ХТЗ) и альгината натрия (АлNa). Интерполимерный комплекс хитозан-альгинат натрия был получен методом смешения эквимолярных растворов полимеров в заданной пропорции. Для синтеза ИПК использованы раствор хитозана в лимонной кислоте и водный раствор альгината натрия. Состав ИПК определен методами гравиметрии, турбидиметрии и динамического лазерного светорассеяния и равен [XT3]:[АлNa] = 2:3. Интерполимерный комплекс образован в результате ион-ионного взаимодействия между катионным полиэлектролитом - хитозаном и анионным полиэлектролитом — альгинатом натрия. Определены агрохимические показатели образцов почвы без и после внесения отдельных биополимеров и ИПК. Обработка почвы отдельными биополимерами и полученным интерполимерным комплексом заметно не повлияла на ее основные агрохимические показатели. В результате лабораторных опытов с отдельными биополимерами и синтезированным ИПК показано, что полученный интерполимерный комплекс является более эффективным средством защиты почвы от водной эрозии по сравнению с отдельными биополимерами - компонентами комплекса. Полученные результаты вегетационных опытов в лабораторных условиях выявили, что обработка почвы ИПК положительно влияет на рост и развитие овощной культуры - огурца. Следовательно, можно заключить, что синтезированный из биополимеров ИПК может быть использован как эффективный экологически безопасный структурообразователь почвы.
\end{abstract}

Ключевые слова: интерполимерный комплекс, биополимер, хитозан, альгинат натрия, состав, почва, структурообразователь.

\section{References}

1 Lü Y.H., Fu B.J., \& Lin L. (2015). Land degradation research: the need for a broader focus. Environmental Science \& Technology, 49, 689-690.

2 Kabanov, V.A., Zezin, A.B., Kasaikin, V.A., Yaroslavov, A.A., \& Topchiev, D.A. (1991). Polyelectrolytes in the solution of ecological problems. Russian Chemical Reviews, 60, 3, 288-291.

3 Chelushkin, P.S., Lysenko, E.A., Bronich, T.K., Eisenberg, A., Kabanov, A.V., \& Kabanov, V.A. (2004). Interpolyelectrolyte complexes of a cationic amphiphilic diblock copolymer and an oppositely charged linear polyanion. Polymer Science. A, 46, 5, 485492 .

4 Zezin, A.B., Mikheikin, S.V., Rogacheva, V.B., Zansokhova, M.F., Sybachin, A.V., \& Yaroslavov, A.A. Polymeric stabilizers for protection of soil and ground against wind and water erosion. (2015). Advances in Colloid and Interface Science, $226,17-23$. 
5 Inagamov, S.Ya., \& Mukhamedov, G.I. (2011). Structure and Physical-Mechanical Properties of Interpolymeric Complexes Based on Sodium Carboxymethylcellulose. Journal of Applied Polymer Science, 122, 3, 1749-1757.

6 Orazzhanova, L.K., Yashkarova, M.G., Bimendina, L.A., \& Kudaibergenov, S.E. (2003). Binary and ternary polymer-strontium complexes and the capture of radioactive strontium-90 from the polluted soil of the Semipalatinsk Nuclear Test Site. Journal of Applied Polymer Science, 87, 5, 759-764.

7 Mussabayeva, B.Kh., Klivenko, A.N., Kassymova, Zh.S., \& Orazzhanova, L.K. (2018). Primenenie interpolimernykh kompleksov v ekolohicheskikh tseliakh [Application of interpolymer complexes in the ecological purposes]. Khimicheskii zhurnal Kazakhstana - Chemical Journal of Kazakhstan, 64, 4, 187-204 [in Russian].

8 Kassymova, Zh.S., Orazzhanova, L.K., Klivenko, A.N., Mussabayeva, B.Kh., \& Asserganov, D.K. (2019). Preparation and Properties of Interpolymer Complexes Capable of Soil Structuring. Russian Journal of Applied Chemistry, 92, 2, $208-217$.

9 Smirnova, N.N. (2018). Interpolielekrolitnoe kompleksoobrazovanie sulfonatsoderzhashcheho aromaticheskoho poliamida $\mathrm{v}$ vodnykh rastvorakh: vliianie prirody poliosnovanii na sostav obrazuiushchikhsia produktov [Interpolyelectrolyte complexation of sulfonate-containing aromatic polyamide in aqueous solutions: the influence of the nature of the polybases on the composition of the formed products]. Vestnik VGUIT - Bulletin of Voronezh State University of Engineering Technologies, 80, 1, $206-210$ [in Russian].

10 Panov, D.A. (2018). Vliianie khitozana na fiziko-khimicheskie svoistva alhinata natriia [Effect of chitosan on the physical and chemical properties of sodium alginate]. Uchenye zapiski Krymskoho federalnoho universiteta imeni V.I. Vernadskoho. Seriia Biolohiia. Khimiia - Scientific notes of the Crimean Federal University named after V.I. Vernadsky. Series Biology. Chemistry, 70, 4, 311319 [in Russian].

11 Kassymova, Zh.S., Orazzhanova, L.K., Bayakhmetova, B.B., Gaisina, B.S., Kassenova, N.B., \& Yelemessova, G.T. (2019). Preparation of interpolymer complexes of chitosan and sodium alginate // Bulletin of the Karaganda University. Chemistry Series, $1(93), 17-24$. 